\title{
Enhancing Lipid Production of Dunaliella tertiolecta by Manipulating the Interactive Effect of Salinity and Nitrogen
}

\author{
M. Rizwan, ${ }^{\mathrm{a}, \mathrm{b}}$ G. Mujtaba, ${ }^{\mathrm{a}, \mathrm{c}}$ N. Rashid, ${ }^{\mathrm{d}}$ and K. Lee ${ }^{\mathrm{a},{ }^{*}}$ \\ ${ }^{a}$ Department of Environmental Engineering and Energy, Myongji \\ University, Yongin, Gyeongki, 17058, Republic of Korea \\ ${ }^{b}$ Department of Environmental Sciences, University of Haripur, \\ 22620, Haripur, Pakistan \\ 'Department of Energy and Environment Engineering, Dawood \\ University of Engineering and Technology, Karachi, 74800, Pakistan \\ ${ }^{\mathrm{d}}$ Department of Chemical Engineering, COMSATS Institute \\ of Information Technology, 55180, Lahore, Pakistan
}

doi: 10.15255/CABEQ.2017.1092

Original scientific paper Received: February 11, 2017 Accepted: September 1, 2017

Low lipid yield is a major bottleneck towards the scale-up application of microalgae for biodiesel production. The focus of this study was to improve the lipid production of Dunaliella tertiolecta (a marine microalga) by altering the concentration of salinity and nitrogen (as nutrients). The unique aspect of this study was to investigate the interactive effect of nitrogen and salinity on lipid production and their correlation with biomass yield and nitrogen uptake. In this experiment, microalgae were grown under various combinations of salinity and nitrogen. At first, lipid production was observed under varied nitrogen concentration $\left(0-75 \mathrm{mg} \mathrm{L}^{-1}\right.$ as $\left.\mathrm{NaNO}_{3}\right)$ and fixed salinity, 37.7 Practical Salinity Unit (PSU). The maximum cell growth rate of $288.4 \mathrm{mg} \mathrm{L}^{-1} \mathrm{~d}^{-1}$ and lipid production of $29.3 \%$ were achieved at $75 \mathrm{mg} \mathrm{L}^{-1}$ of $\mathrm{NaNO}_{3}$. Now, this concentration of nitrogen was fixed and the effects of salinity concentrations were observed. The lipid production increased to $34 \%$, and cell growth rate decreased to $201.3 \mathrm{mg} \mathrm{L}^{-1} \mathrm{~d}^{-1}$ at $3.77 \mathrm{PSU}$ of salinity. However, further reduction of the nitrogen concentration down to $18.75 \mathrm{mg} \mathrm{L}^{-1}$ of $\mathrm{NaNO}_{3}$ increased the lipid production to $42 \%$ and decreased biomass to $0.64 \mathrm{~g} \mathrm{~L}^{-1}$. It was also found that lipid production was linearly correlated with nitrogen uptake. Microalgae cells consumed all of the nitrogen in the first 24 hours of acclimation; however, lipid yield did not change much over time.

Key words:

marine microalgae, nitrogen, salinity, biomass, lipid

\section{Introduction}

Overuse of fossil fuels has led to finding renewable, environmentally friendly, and cost-effective energy resources. ${ }^{1}$ Since conventional energy resources are neither cheap nor environmentally friendly. Conventional energy resources produce $\mathrm{CO}_{2}$ (greenhouse gas), which is a potential threat to the environmental recipients. In this perspective, biofuels production has emerged as a potential alternative. Among biofuels, biodiesel is the most attractive choice, inherited with the traits of sustainability. A number of feedstocks can be used to produce biodiesel. ${ }^{2}$ However, extraction of biodiesel from microalgae offers unique advantages over other feedstocks. Microalgae offer fast growth rate, high carbohydrate, lipid, and have the ability to grow under harsh conditions. ${ }^{3}$

${ }^{*}$ Corresponding author: e-mail: kisay@mju.ac.kr; Tel: +82-31-330-6689, Fax: +82-31-336-6336.
Besides the unique features of microalgae, their scale-up applications for biofuels production is as yet uneconomical. ${ }^{4}$ Actually, the current level of lipid production (30-40\% of cell biomass) is much lower than its potential. ${ }^{5}$ Thus, there is a need to improve the lipid production of microalgae. A number of strategies have been applied in the past to improve lipid production. ${ }^{6-8}$ However, nutrients control is considered a key to improving biomass and lipid yield. Rate of nutrients uptake in microalgae is different at different stage of microalgal growth. In lag phase, they require low nutrients due to low cell density. In exponential phase, they consume maximum nutrients to develop their cell biomass. However, in late-exponential or stationary phase, they shift their mechanism from biomass development to lipid and carbohydrate production. A number of studies have revealed that microalgae cells produce more lipids when exposed to nutrient-starved conditions in late exponential or stationary phase. Among 
nutrients, nitrogen is a key element, which plays a major role in microalgal growth. Microalgae during nitrogen-rich conditions produce more protein than lipids; whereas, during nitrogen-starved conditions, the cells cannot synthesize protein due to less availability of nitrogen (a protein source). Thus, microalgae start to accumulate lipids. It is also reported that marine microalgae growth largely depends on salinity concentration along with nitrogen. Studies have demonstrated the effect of nitrogen and salinity individually. However, we hypothesized that nitrogen and salinity might have an interactive effect on microalgae growth. Optimization of this interaction might return high biomass and lipid yield. Thus, the scope of this study was to investigate the interactive effect of nitrogen and salinity. The approach of this work is different from typical studies available, which focus on investigating the effect of nitrogen, and salinity (as an independent element) instead of studying their interactive effect.

The purpose of this study was to assess the dependence of lipid production in Dunaliella tertiolecta (a marine microalga) upon different concentrations of salinity and nitrogen. The interactive effect of these two factors on lipid production, biomass yield, and nitrogen uptake was also investigated. A two-phase cultivation system was adopted; cells were actively grown in phase- 1 under optimal environmental conditions. The cells in early stationary phase were transferred to phase-2, where cells were exposed to various concentration combinations of nitrogen and salinity. ${ }^{6,8}$

\section{Materials and methods}

\section{Algal strain and culture conditions}

Marine microalga Dunaliella tertiolecta (UTEX LB999) was obtained from the culture collection of the University of Texas, Austin, USA. Sterilized f/2 medium having $75 \mathrm{mg} \mathrm{L}^{-1}$ of $\mathrm{NaNO}_{3}, 4.32 \mathrm{mg} \mathrm{L}^{-1}$ $\mathrm{NaH}_{2} \mathrm{PO}_{4}, 0.023 \mathrm{mg} \mathrm{L}^{-1} \mathrm{ZnSO}_{4} \cdot 7 \mathrm{H}_{2} \mathrm{O}, 0.217 \mathrm{mg} \mathrm{L}^{-1}$ $\mathrm{MnSO}_{4} \cdot 5 \mathrm{H}_{2} \mathrm{O}, 0.0073 \mathrm{mg} \mathrm{L}-1 \mathrm{Na}_{2} \mathrm{MoO}_{4} \cdot 2 \mathrm{H}_{2} \mathrm{O}, 0.014$ $\mathrm{mg} \mathrm{L}^{-1} \mathrm{CoSO}_{4} \cdot 7 \mathrm{H}_{2} \mathrm{O}, 0.0068 \mathrm{mg} \mathrm{L}^{-1} \mathrm{CuCl}_{2} \cdot 2 \mathrm{H}_{2} \mathrm{O}$, $3.15 \mathrm{mg} \mathrm{L}^{-1}, \mathrm{FeCl}_{3} \cdot 6 \mathrm{H}_{2} \mathrm{O}, 4.4 \mathrm{mg} \mathrm{L}^{-1} \mathrm{Na}_{2}$ EDTA $2 \mathrm{H}_{2} \mathrm{O}$ and vitamins, supplemented with artificial seawater (MBL) having $24.72 \mathrm{~g} \mathrm{~L}^{-1}$ of $\mathrm{NaCl}, 0.67 \mathrm{~g} \mathrm{~L}^{-1} \mathrm{KCl}$, $1.36 \mathrm{~g} \mathrm{~L}^{-1} \mathrm{CaCl}_{2} \cdot 2 \mathrm{H}_{2} \mathrm{O}, 4.66 \mathrm{~g} \mathrm{~L}^{-1} \mathrm{MgCl}_{2} \cdot 6 \mathrm{H}_{2} \mathrm{O}$, $6.29 \mathrm{~g} \mathrm{~L}^{-1} \mathrm{MgSO}_{4} \cdot 7 \mathrm{H}_{2} \mathrm{O}, 0.18 \mathrm{~g} \mathrm{~L}^{-1}$ of $\mathrm{NaHCO}_{3}$ and $0.606 \mathrm{~g} \mathrm{~L}^{-1}$ of Tris. ${ }^{9}$ At first, seed culture was grown in $100 \mathrm{~mL}$ of $\mathrm{f} / 2$ medium using $250 \mathrm{~mL}$ flask in shaking incubator under light intensity of $80-100$ $\mu \mathrm{E} \mathrm{m} \mathrm{m}^{-2} \mathrm{~s}^{-1}$ at $25{ }^{\circ} \mathrm{C}$. When stationary phase was reached, the cells were shifted to glass bubblecolumn photo bioreactor.

Cells were grown photoautotrophically at $25{ }^{\circ} \mathrm{C}$ in $1 \mathrm{~L} \mathrm{f} / 2$ medium in a bubble-column photo-bioreactor (internal diameter $6.5 \mathrm{~cm}$; height, $37 \mathrm{~cm}$ ). ${ }^{10}$
Air mixed with $\mathrm{CO}_{2}(5 \%)$ after passing through 0.2 $\mu \mathrm{m}$ PTFE membrane filter was supplied to the cells at a rate of $0.2 \mathrm{vvm}$. A continuous white fluorescent light $\left(100 \mu \mathrm{E} \mathrm{m}^{-2} \mathrm{~s}^{-1}\right)$ was supplied to the cells.

\section{Experimental}

Two-phase cultivation system was adopted in this study. In the first phase, the cells density of 1.5-2.0 $\mathrm{g} \mathrm{L}^{-1}$ was achieved at the optimal growth conditions in a glass bubble-column photo-bioreactor. In phase-2, the cells in stationary phase were transferred to a nutrient-deprived medium in glass bubble-column photo-bioreactor (according to the experimental design). Afterward, the cells were harvested by centrifugation at $3000 \mathrm{rpm}$ for $5 \mathrm{~min}$, and separated from the spent medium. The collected cells were washed several times with sterilized distilled water for lipids extraction.

\section{Analyses}

\section{Biomass concentration}

A correlation between growth rate and cell density $\left(\mathrm{OD}_{680}\right)$ was developed. The optical density of the cells was measured regularly at $680 \mathrm{~nm}$ using UV/VIS spectrophotometer (DR-4000U, Hach, USA). For conversion of $\mathrm{OD}_{680}$ values into biomass, calibration curve between $\mathrm{OD}_{680}$ and dry cell weight was used by determining the conversion factor (i.e., $0.428 \mathrm{OD}_{680}$ equals approximately $0.96 \mathrm{CDM} \mathrm{g} \mathrm{L}^{-1}$ ). The cell dry mass was (CDM) calculated by filtering the cells through acetate membrane filter $(0.7 \mu \mathrm{m}$ pore size, $47 \mathrm{~mm}$ in diameter, Whatman, UK) and drying in an oven at $80{ }^{\circ} \mathrm{C}$ for 12 hours.

\section{Lipid analysis}

Total cellular lipids were extracted using 40 $\mathrm{mL}$ of suspended cells. These cells were harvested by means of centrifugation (3,000 rpm for $5 \mathrm{~min}$ ). For the extraction of lipid from harvested cells, 7.6 $\mathrm{mL}$ mixture of chloroform/methanol/water $(1 / 2 / 0.8$, $\mathrm{v} / \mathrm{v} / \mathrm{v}$ ) was used. Sonication of mixture was carried out at $100 \mathrm{~W}$ and $20 \mathrm{kHz}$ for 1 minute (VCX 130, Sonics and Materials Inc., USA), and later the mixture was vortexed for $30 \mathrm{sec}$. In order to make the final ratio of chloroform/methanol/water: 1/1/0.9 $(\mathrm{v} / \mathrm{v} / \mathrm{v}), 2 \mathrm{~mL}$ of chloroform and water each were added to the above mixture, and vortexed again for $30 \mathrm{sec}$. This mixture was centrifuged again at 3,000 $\mathrm{rpm}$ for $5 \mathrm{~min}$ in order to fractionate the mixture into three layers. The uppermost layer of methanol was separated, while the bottom layer of chloroform containing lipid was collected in a new tube. The upper layer of methanol was extracted twice using the above process. The chloroform layers were combined and evaporated in a drying oven at 

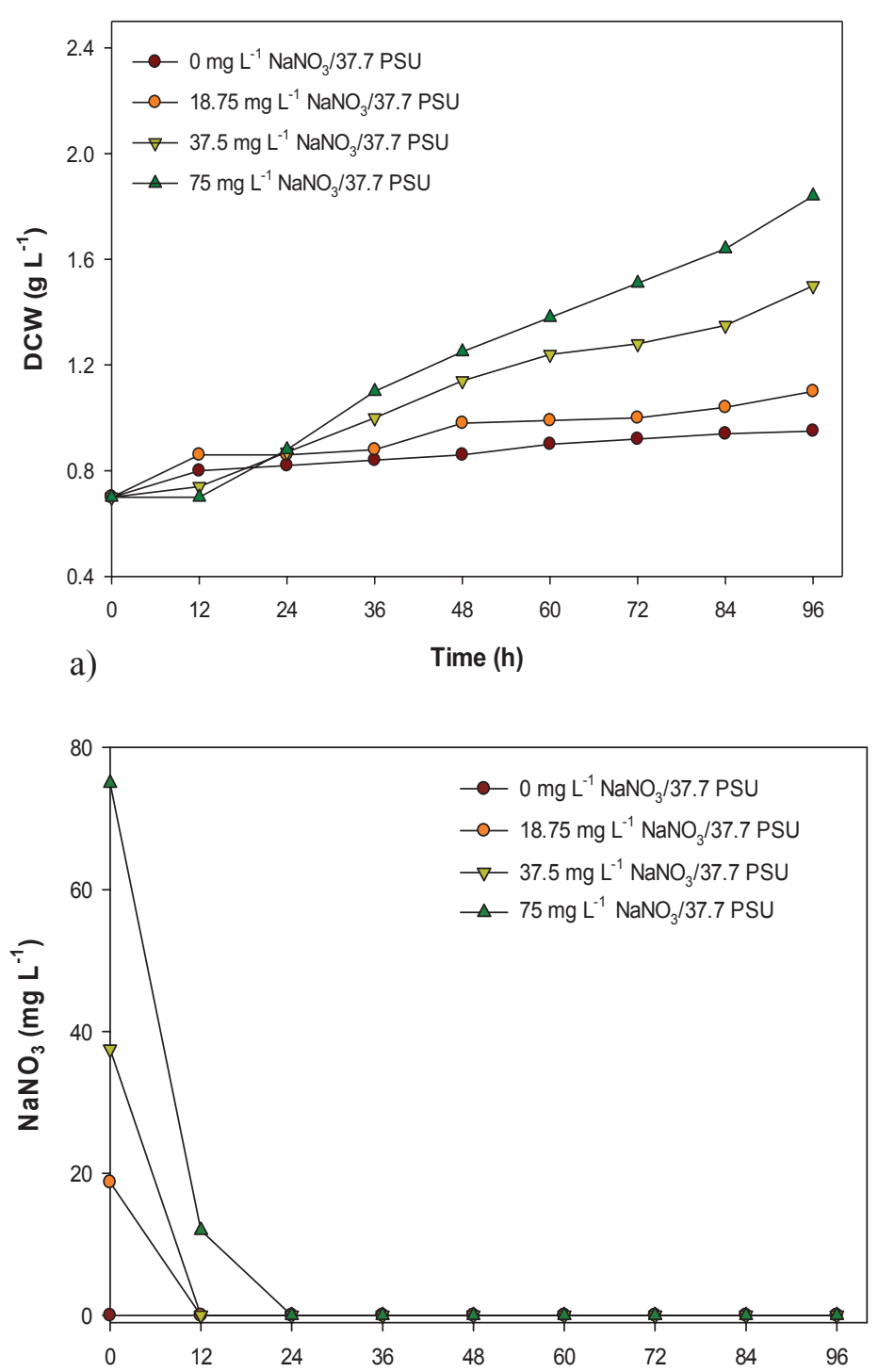

b)

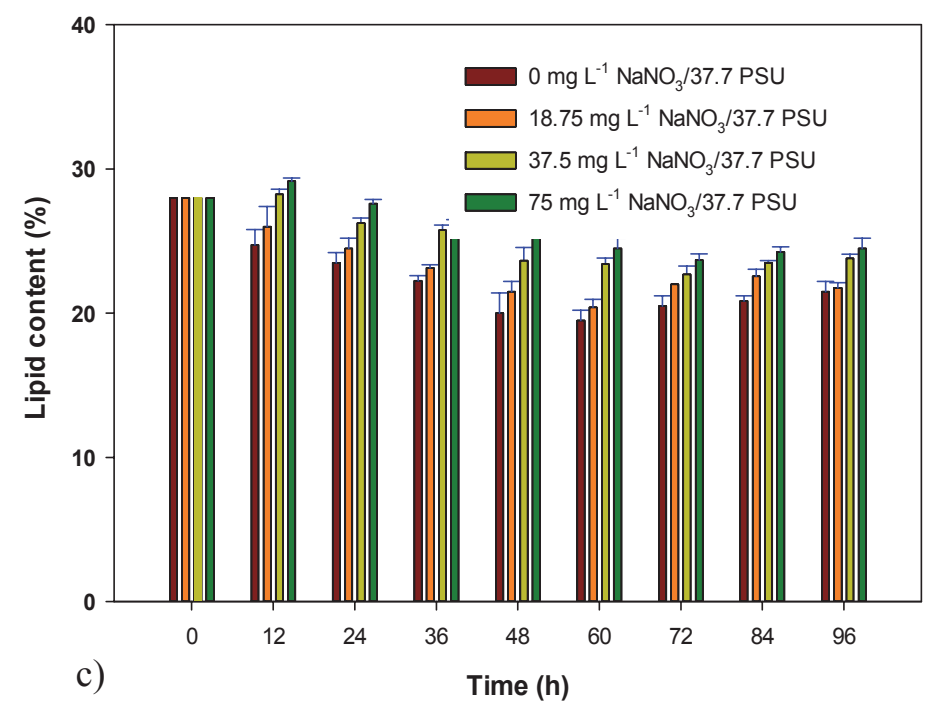

Fig. 1 - Effect of nitrogen variation on (a) cell dry mass, (b) nitrogen consumption, and (c) lipid content under normal salinity (37.7 PSU)
$80{ }^{\circ} \mathrm{C}$ for $24 \mathrm{~h}$. The total lipid contents were expressed as the $\%$ of cell dry mass (CDM).

\section{Lipid productivity}

Lipid productivities were calculated from the initial cell dry mass and final cell dry mass from the equation used by Griffiths and Harrison: ${ }^{11}$

$$
\frac{\left\{\left(\mathrm{CDM}_{t} \cdot \operatorname{Lipid}_{t}\right)-\left(\mathrm{CDM}_{t_{0}} \cdot \operatorname{Lipid}_{t_{0}}\right)\right\}}{\left(t-t_{0}\right)}
$$

where $\mathrm{CDM}_{t}$ and Lipid $_{t}$ are the final CDM and lipid contents, respectively, while $\mathrm{CDM}_{t_{0}}$ and Lipid $t_{t_{0}}$ are initial CDM and lipid content, respectively. Similarly, $t$ and $t_{0}$ are final and initial time, respectively.

\section{Nitrate}

Standard method (APHA, 1995) of reading multi-wavelength UV absorbance was used for nitrate measurements. ${ }^{12}$

\section{Results and discussion}

\section{Effect of nitrogen concentration}

Inorganic nitrogen is an essential element for the growth of microalgae. ${ }^{13}$ Microalgae use nitrogen for their metabolic activities. During nitrogen-rich conditions, the cells use nitrogen to develop biomass. However, under nitrogen stress, they change the metabolism from biomass development to lipid or carbohydrate production, and they fix carbon through photosynthesis. ${ }^{14}$ In order to unravel the effect of nitrogen, $D$. tertiolecta was subjected to various concentrations of $\mathrm{NaNO}_{3}$ at fixed level of salinity (37.7 PSU). The growth was linearly correlated with a change in initial concentration of $\mathrm{NaNO}_{3}$ (Fig. 1a). The highest growth was achieved with $75 \mathrm{mg} \mathrm{L}^{-1}$ of $\mathrm{NaNO}_{3}$. The lowest biomass was observed when nitrogen was depleted from the medium. The growth of Dunaliella in the absence of nitrogen might be due to the release of internal nitrogen from the cells. ${ }^{15}$

The nitrogen uptake was observed in D. tertiolecta with time (Fig. 1b). Microalgae consumed all $\mathrm{NaNO}_{3}$ within 12 hours, except for $75 \mathrm{mg} \mathrm{L}^{-1}$ dose. The cells with this concentration also consumed most of the nitrogen in the first 12 hours; however, it took another 12 hours ( 24 in total) to consume all the nitrogen. Nitrogen is one of the most important nutrients affecting lipid metabolism in microalgae. It has been reported that several microalgal species increase the accumulation of lipids under nitrogen-deprived conditions. ${ }^{14}$ However, Fig. 1c shows that nitrogen stress did not result in lipid accumulation in D. tertiolecta. The lipid content did not change much with time. Nevertheless, there was a 

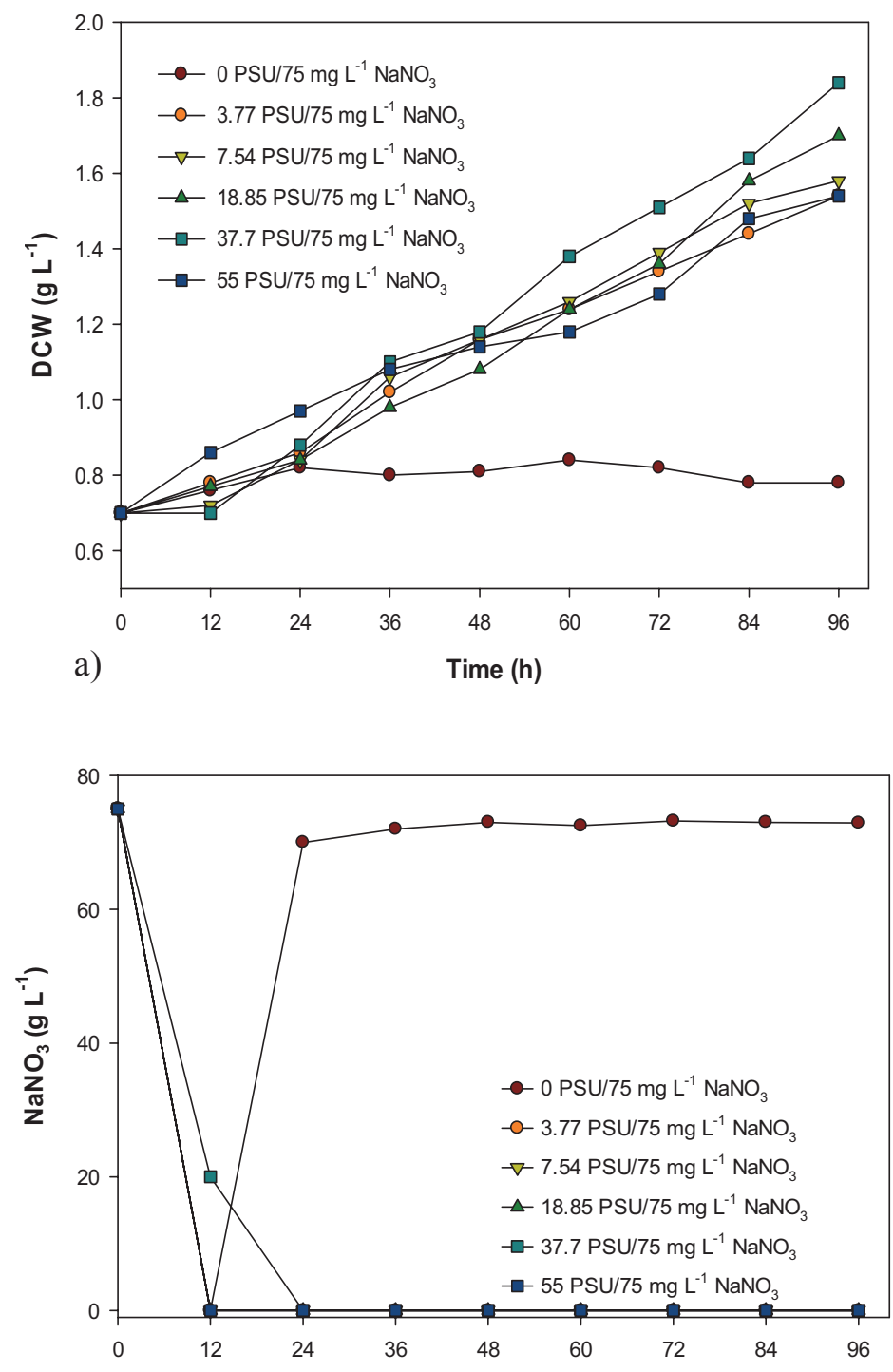

b)

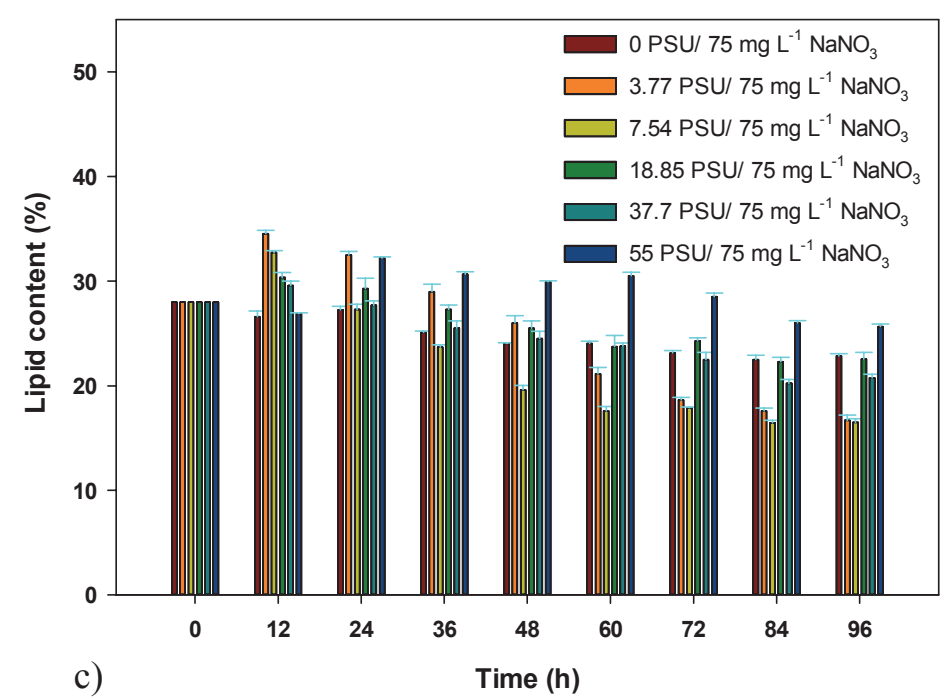

Fig. 2 - Effect of salinity variation on (a) cell dry mass, (b) nitrogen consumption, and (c) lipid content under $75 \mathrm{mg} \mathrm{L}^{-1}$ of $\mathrm{NaNO}_{3}$ slight increase in lipid content after 12 hours at 75 $\mathrm{mg} \mathrm{L}^{-1}$ of $\mathrm{NaNO}_{3}$. Both the lipid content $(29 \%)$ and lipid productivity $\left(61 \mathrm{mg} \mathrm{L}^{-1} \mathrm{~d}^{-1}\right)$ were maximal at $75 \mathrm{mg} \mathrm{L}^{-1}$ of $\mathrm{NaNO}_{3}$, which was the highest initial nitrate concentration used in this study. These results were supported by a previous study on Dunaliella where nitrogen stress alone did not result in lipid enhancement. ${ }^{16}$ Thus, we investigated whether the combined effect of salinity and nitrogen might induce any positive influence on lipid production in D. tertiolecta. ${ }^{14}$

\section{Effect of salinity}

The effect of different concentrations (0-55 PSU) of salinity was compared when the concentration of nitrogen was fixed at $75 \mathrm{mg} \mathrm{L}^{-1}$ of $\mathrm{NaNO}_{3}$. Fig. 2a shows that the decrease in biomass production was observed with decreasing salinity from 37.7 PSU. A negative impact of salinity was found above 37.3 PSU, the normal seawater salinity. It is pertinent to mention that the optimum level of salinity (37.7 PSU) was equivalent to the salinity level of one dose of the $f / 2$ medium. The lipids production was also high at 37.7 PSU in the early stage of cultivation, but higher salinity resulted in better lipid production in a later stage, after $36 \mathrm{~h}$ (Fig. 2c).

It was observed that the salinity above or below the optimal range (37.7 PSU) posed a negative impact on the lipids synthesis. Similar results were found in a study on Nannochloropsis sp by Khatoon. ${ }^{17}$ Jahnke and White observed that low salinity conditions changed Dunaliella to have enlarged cell size, decreased carbonate pool, and increased production of $\alpha$-tocopherol and total glutathione. ${ }^{18}$ Our results are in agreement with the previous studies on Dunaliella where increased salinity had resulted in slow growth. ${ }^{17-22}$ In fact, increased salinity could inhibit photosynthesis in microalgae. ${ }^{19,23}$ The mechanism of this inhibition is the destruction of repair cycle of photo-damaged PS-II via suppression of protein de novo synthesis, especially D1 protein of the PS II at high salinity. ${ }^{25}$ Meanwhile, the absence of salt in the medium disabled the microalgae to grow and uptake nutrients. ${ }^{23,6}$ The presence of salts in the medium is essential for marine microalga growth and lipid synthesis.

Fig. $2 b$ shows that almost all of the nitrogen was consumed between 12-24 hours. The maximum lipid content was observed between 12 24 hours of cultivation (Fig. 2c). After the depletion of nitrogen from the medium, the lipid contents decreased slowly overall as time passed. It is noted that the salinity $>37.7$ PSU tended to give increased lipid content than that in 37.7 PSU, which implied that extreme salinity conditions acted as a stress to enhance lipid synthesis. Salinity stress affects several physiological and biochemical mechanisms of 

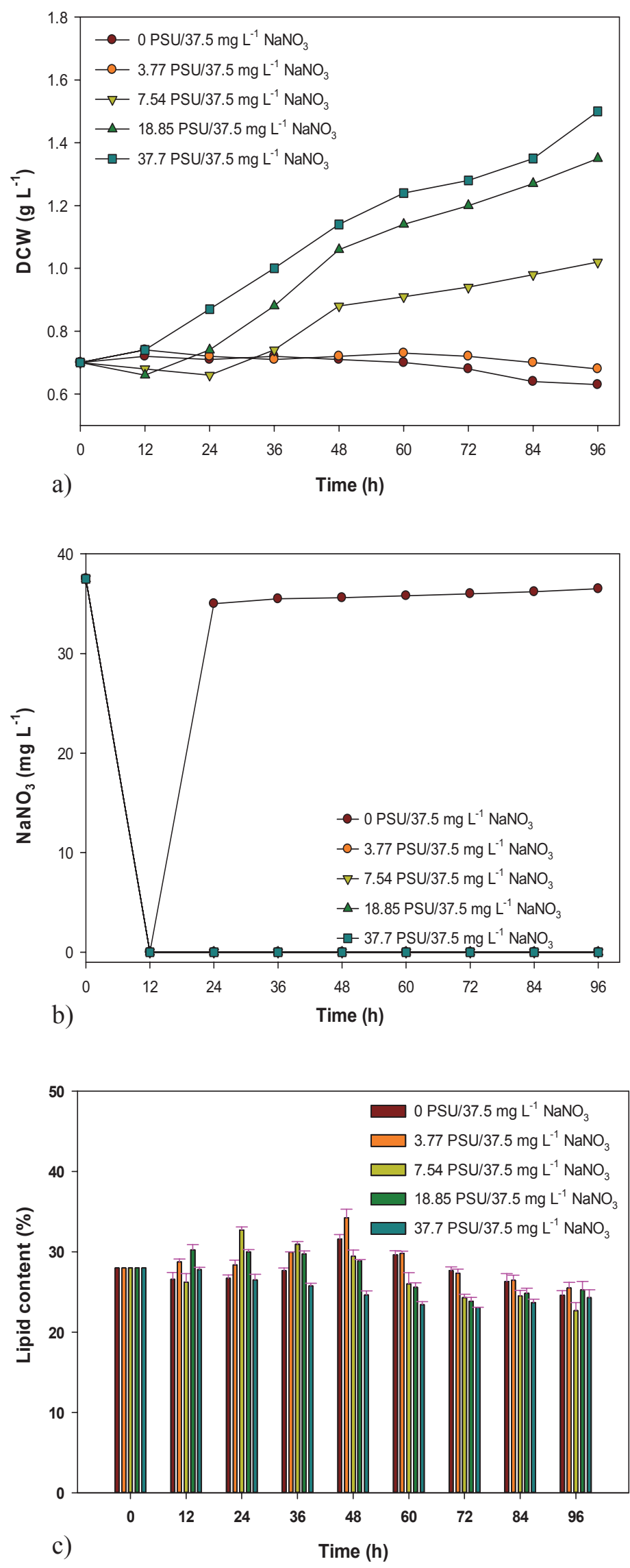

Fig. 3 - Effect of salinity variation and fixed nitrogen (37.5 $m g L^{-1}$ ) on (a) dry cell weight, (b) nitrogen consumption rate, (c) lipid content microalgae. Salinity stress also causes changes in the fatty acid metabolism of microalgae, which ultimately results in lipid enhancement. ${ }^{26}$ It is also known that a high salinity can induce saturation of fatty acid, which can change the properties of produced biofuels. ${ }^{27,28}$

\section{Interactive effect of salinity and nitrogen}

Fig. 3 shows the effect of salinity on biomass, and lipids contents by adjusting the nitrogen level at $37.5 \mathrm{mg} \mathrm{L}{ }^{-1}$. The biomass increased with an increase in salinity (Fig. 3a) while at low salinity (3.77 PSU), the biomass initially decreased. However, in the absence of salts, biomasses gradually decreased and the cells died. Marine microalgae grow best at salinity equals to marine water. Therefore, any change in salinity level negatively affects microalgal growth. Our results are supported by previous studies on marine microalgae where low salinity level adversely affects growth. ${ }^{17,18}$ The maximum biomass was achieved at the highest salinity level of 37.7 PSU. However, this increase in biomass was lower compared to the previous experiment which was performed under salinity variation alone. This shows that this concentration of $\mathrm{NaNO}_{3}$ was not optimum for normal cell growth.

Fig. $3 b$ shows that, under all salinity conditions, nitrogen was consumed within 12 hours. However, due to the cell death in the medium without salts, nitrogen was released back into the medium. The same was the case when salinity variation experiment was performed alone, which shows that the presence of the optimum level of salt in the medium is necessary for cell survival. The presence of salts in the medium is essential for nutrients uptake and cells survival. ${ }^{23,26}$

Fig. 3c shows that the lowest salinity, i.e., 3.77 PSU, and intermediate level of $\mathrm{NaNO}_{3}\left(37.5 \mathrm{mg} \mathrm{L}^{-1}\right)$ resulted in the maximum lipid content, i.e., $34 \%$. Although lipid content slightly increased in our previous experiment at the lowest salinity level (3.77 PSU) and N-replete conditions, an increase in lipid content was higher in this case. These results show that the combined salinity and nitrogen stress was essential for lipid enhancement in Dunaliella tertiolecta. Our results are supported by Dan Cheng et al. study, which also suggested that combined application of multiple stress factors could be more effective in improving biofuel yield than the application of single stress factor. ${ }^{14}$ Lipid content increased in our previous experiment of salinity stress in the presence of an intermediate level of $\mathrm{NaNO}_{3}$ (37.5 $\mathrm{mg} \mathrm{L}^{-1}$ ). Previous results revealed that lowering the concentration of $\mathrm{NaNO}_{3}$ governs high lipid productivity. With this in mind, further experiments were carried out in which $\mathrm{NaNO}_{3}$ concentration was 

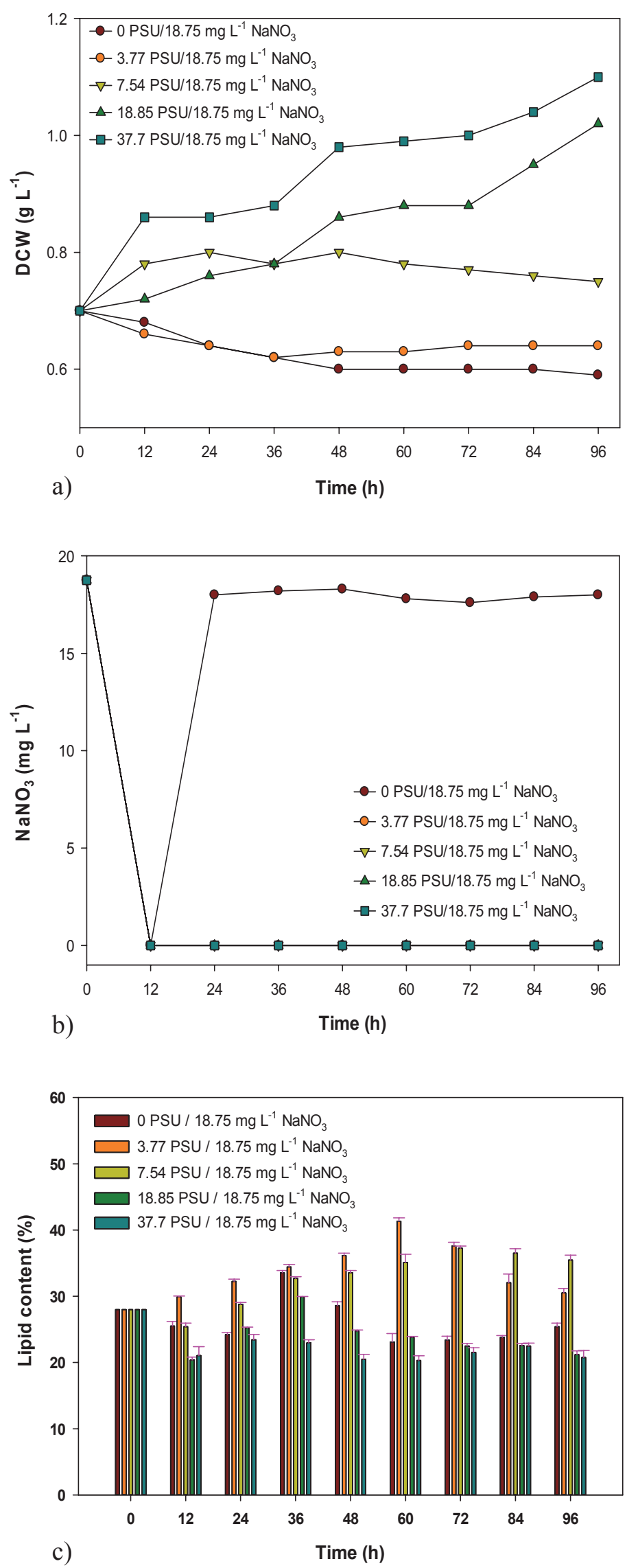

Fig. 4 - Effect of salinity variation and fixed nitrogen (18.75 $m g L^{-1}$ ) on (a) dry cell weight, (b) nitrogen consumption rate, (c) lipid content further reduced to $18.85 \mathrm{mg} \mathrm{L}^{-1}$; varied concentrations of salinity were employed. Fig. 4a shows that biomass in all cultures increases except for the cultures without salt and with the lowest salinity, i.e., 3.77 PSU. However, due to the presence of low nitrogen level in all cultures, biomass increase was less than that intermediate fixed levels, $37.5 \mathrm{mg} \mathrm{L}^{-1}$ and high $75 \mathrm{mg} \mathrm{L}^{-1}$ of $\mathrm{NaNO}_{3}$. This was due to an insufficient concentration of $\mathrm{NaNO}_{3}$ in the medium. Several studies on marine microalgae had shown that low salinity resulted in reduced cell growth. ${ }^{17,23}$ Jahnke et al. also reported a decrease in marine microalga growth at low salinity level. ${ }^{18}$

Fig. $4 \mathrm{~b}$ shows the nitrogen consumption in salinity stress experiment. All the cultures completely consumed nitrogen within 12 hours. However, the culture without salts released nitrogen back into the culture medium due to cell death. Similar results were reported by Hellebust et al. ${ }^{23}$ In their study, microalgae did not grow at low salinity, while in the absence of salts they showed low nutrient uptake. As for marine microalgae, salinity is one of the most important factors affecting their growth, lipid content, and biochemical composition..$^{15,16}$

Fig. 4c shows lipid content increase in the cultures having low salinity, i.e., 3.77 PSU and 7.54 PSU. The maximum lipid content of $42 \%$ was achieved at 3.77 PSU of salinity. The lipid contents under this condition were the highest compared to previous salinity variation experiments, which were performed under N-replete condition. This shows that at low salinity level and low $\mathrm{N}$ in the medium, lipid content can be enhanced. Our results are in agreement with the findings of Pal et al., where lower salinity improved lipid production at high light and nitrogen stress conditions. ${ }^{15}$ Yao et al. also found starch accumulation enhanced in the presence of nitrogen stress and low salinity. ${ }^{29}$ It appeared that salinity alone cannot be considered as a manipulation factor for enhanced lipid accumulation in $D$. tertiolecta. The next salinity variation experiment was performed in the absence of nitrogen. There was no significant increase in biomass and lipid content at all salinities in the absence of nitrogen (data not shown). Adams et al. also reported that only a certain degree of nitrogen stress on microalgae could result in lipid accumulation. ${ }^{30}$ It shows that this specie prefers low salinity and low nitrogen level for lipid enhancement.

\section{Comparison of lipid productivity}

Experimental results in Figs. 1 and 2 show that D. tertiolecta grew well in normal seawater salinity and under high nitrate conditions. Cellular lipid content enhanced under high nitrate conditions and at high salinity conditions. Since lipid content devi- 


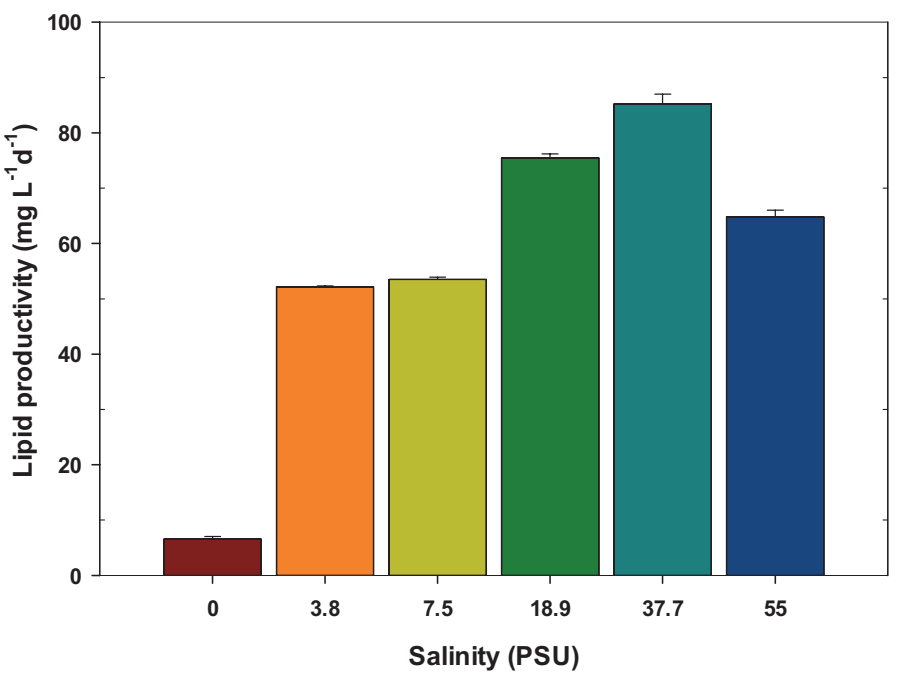

(a) Salinity 37.7 PSU

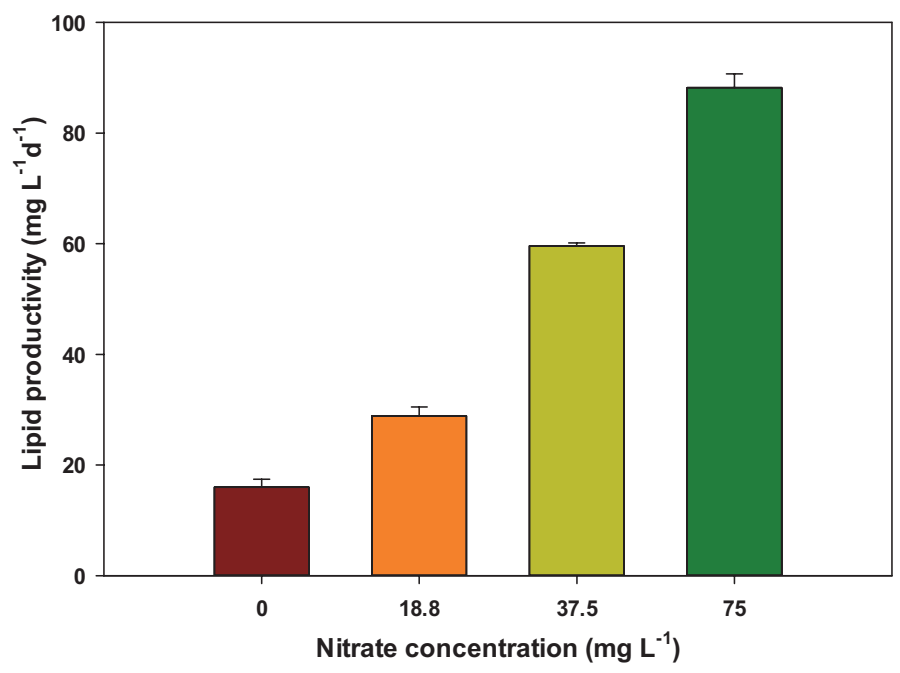

(b) $\mathrm{NaNO}_{3} 75 \mathrm{mg} \mathrm{L}{ }^{-1}$

Fig. 5 - Comparison of lipid productivity depending upon different nitrate concentrations and salinity conditions

ation was not largely dependent upon salinity or nitrate variations, it was not easy to deduce an optimal condition for lipid production directly from Figs. 1 and 2. Therefore, lipid productivity was calculated based upon the average cell growth rates and cellular lipid content. Lipid productivity (as $\mathrm{mg} \mathrm{L}^{-1} \mathrm{~d}^{-1}$ ) can be calculated from the product of cell growth rate (as $\mathrm{mg} \mathrm{L}^{-1} \mathrm{~d}^{-1}$ ) and lipid content (as $\mathrm{w} / \mathrm{w} \%$ ).

Table 1 (as supplementary material) shows the cell growth rates, cellular lipid contents, and the estimated lipid productivity values at different salinity and nitrate concentrations. Comparisons of the resulting lipid productivity were made in Fig. 5. Cell growth rate and cellular lipid content were enhanced when initial nitrate concentration was increased.
The same was valid when the salinity was increased up to 37.7 PSU. It is noted that, although lipid content was the highest at high salinity conditions (55 PSU), lipid productivity was best at normal salinity 37.7 PSU, because cell growth rate was reduced at the high salinity condition.

In the presence of $75 \mathrm{mg} \mathrm{L}^{-1}$ of $\mathrm{NaNO}_{3}$ lipid productivity was the maximum. As the concentration of $\mathrm{NaNO}_{3}$ was decreased in the medium, it also resulted in a decrease in lipid productivity. In case of salinity variation, 3.77 PSU showed the maximum lipid productivity $\left(140 \mathrm{mg} \mathrm{L}^{-1} \mathrm{~d}^{-1}\right)$. Salinity variation under intermediate nitrogen level resulted in the maximum lipid productivity of $54.1 \mathrm{mg} \mathrm{L}^{-1} \mathrm{~d}^{-1}$ in the presence of 18.85 PSU. While salinity variation in the presence of low nitrogen returned the maximum lipid productivity of $38.33 \mathrm{mg} \mathrm{L}^{-1} \mathrm{~d}^{-1}$ in the presence of 7.54 PSU. The lipid productivity of Dunaliella tertiolecta under different nitrogen and salinity variations was better than the lipid productivity of most of the 30 microalgal strains studied by Rodolfi et al. ${ }^{30}$ Similarly, lipid productivity of our specie was better than that of Dunaliella sp as reported by Mata et al. $^{32}$

\section{Conclusions}

Nitrogen starvation is popularly used to induce lipid synthesis in many microalgae species; however, the present marine microalga $D$. tertiolecta was an exception, showing reduced lipid content under low nitrogen concentrations. Lipid content did not increase even when all nitrogen was depleted due to the consumption by cell growth. Lipid synthesis was induced under high salinity stress; meanwhile, cell growth was the best at normal seawater salinity. The optimized conditions for the highest lipid productivity was $75 \mathrm{mg} \mathrm{L}^{-1} \mathrm{~d}^{-1}$ of $\mathrm{NaNO}_{3}$, which are the normal nitrogen level of $\mathrm{f} / 2$ medium and normal seawater salinity.

\section{Supplementary Materials}

Table 1 - Effect of nitrogen variation on biomass, lipid content, and lipid productivity

\begin{tabular}{c|c|c|c}
\hline $\begin{array}{c}\mathrm{NaNO}_{3} \\
\left(\mathrm{mg} \mathrm{L}^{-1}\right)\end{array}$ & $\begin{array}{c}\text { Maximum } \\
\text { biomass } \\
\left(\mathrm{g} \mathrm{L}^{-1}\right)\end{array}$ & $\begin{array}{c}\text { Maximum } \\
\text { lipid content } \\
(\%)\end{array}$ & $\begin{array}{c}\text { Maximum } \\
\text { lipid } \\
\text { productivity } \\
\left(\mathrm{mg} \mathrm{L}^{-1} \mathrm{~d}^{-1}\right)\end{array}$ \\
\hline 75 & 1.84 & 29 & 61.4 \\
37.7 & 1.5 & 28 & 40.5 \\
18.75 & 1.1 & 25 & 38 \\
0 & 0.95 & 24 & 0.88 \\
\hline
\end{tabular}


Table 2 - Effect of salinity variation on biomass, lipid content, and lipid productivity

\begin{tabular}{c|c|c|c}
\hline Salinity PSU & $\begin{array}{c}\text { Maximum } \\
\text { biomass } \\
\left(\mathrm{g} \mathrm{L}^{-1}\right)\end{array}$ & $\begin{array}{c}\text { Maximum } \\
\text { lipid content } \\
(\%)\end{array}$ & $\begin{array}{c}\text { Maximum } \\
\text { lipid } \\
\text { productivity } \\
\left(\mathrm{mg} \mathrm{L}^{-1} \mathrm{~d}^{-1}\right)\end{array}$ \\
\hline 55 & 1.54 & 32 & 114.1 \\
37.7 & 1.84 & 29 & 52.7 \\
18.85 & 1.7 & 30 & 70 \\
7.54 & 1.58 & 32.5 & 76 \\
3.77 & 1.54 & 34 & 140 \\
0 & 0.78 & 27 & 25.4 \\
\hline
\end{tabular}

Table 3 -Effect of salinity variation and intermediate nitrogen $\left(37.5 \mathrm{mg} \mathrm{L}^{-1}\right)$ on biomass, lipid content, and lipid productivity

\begin{tabular}{c|c|c|c}
\hline Salinity PSU & $\begin{array}{c}\text { Maximum } \\
\text { biomass } \\
\left(\mathrm{g} \mathrm{L}^{-1}\right)\end{array}$ & $\begin{array}{c}\text { Maximum } \\
\text { lipid content } \\
(\%)\end{array}$ & $\begin{array}{c}\text { Maximum } \\
\text { lipid } \\
\text { productivity } \\
\left(\mathrm{mg} \mathrm{L}^{-1} \mathrm{~d}^{-1}\right)\end{array}$ \\
\hline 37.7 & 1.5 & 28 & 40.5 \\
18.85 & 1.35 & 30 & 54.1 \\
7.54 & 1.02 & 32 & 29.16 \\
3.77 & 0.68 & 33 & 22.6 \\
0 & 0.63 & 31 & 12.7 \\
\hline
\end{tabular}

Table 4 - Effect of salinity variation and low nitrogen (18.75 $\left.m g L^{-1}\right)$ on biomass, lipid content, and lipid productivity

\begin{tabular}{c|c|c|c}
\hline Salinity PSU & $\begin{array}{c}\text { Maximum } \\
\text { biomass } \\
\left(\mathrm{g} \mathrm{L}^{-1}\right)\end{array}$ & $\begin{array}{c}\text { Maximum } \\
\text { lipid content } \\
(\%)\end{array}$ & $\begin{array}{c}\text { Maximum } \\
\text { lipid } \\
\text { productivity } \\
\left(\mathrm{mg} \mathrm{L}^{-1} \mathrm{~d}^{-1}\right)\end{array}$ \\
\hline 37.7 & 1.1 & 25 & 10.40 \\
18.85 & 1.02 & 30 & 24.81 \\
7.54 & 0.75 & 37 & 38.33 \\
3.77 & 0.64 & 42 & 26.68 \\
0 & 0.59 & 33 & 6.9 \\
\hline
\end{tabular}

\section{ACKNOWLEDGEMENT}

This research was supported by a grant from the Marine Biotechnology Program (PJT200255, Development of Marine Microalgal Biofuel Production Technology) funded by the Ministry of Oceans and Fisheries of Korea.

\section{References}

1. Soares, F. R., Martins, G. Seo, E. S. M., An assessment of the economic aspects of $\mathrm{CO}_{2}$ sequestration in a route for biodiesel production from microalgae, Environ. Technol. 34 (2013) 17777.

doi: https://doi.org/10.1080/09593330.2013.816784

2. Felizardo, P., Correia, M. J. N., Raposo, I., Mendes, J. F., Berkemeier, R., Bordado, J. M., Production of biodiesel from waste frying oil, Waste. Manag. 26 (5) 94.

doi: https://doi.org/10.1016/j.wasman.2005.02.025

3. Gorain, P. C., Bagchi, S. K., Mallick, N., Effects of calcium, magnesium and sodium chloride in enhancing lipid accumulation in two green microalgae, Environ. Technol. 34 (2013) 1887.

doi: https://doi.org/10.1080/09593330.2013.812668

4. Bahadar, A., Khan, M. B., Progress in energy from microalgae: A review, Renew. Sustainable Energy Rev. 27 (2013) 128.

doi: https://doi.org/10.1016/j.rser.2013.06.029

5. Gendy, T. S., El-Temtamy, S. A., Commercialization potential aspects of microalgae for biofuel production: an overview, Egyptian Journal of Petroleum 22 (2013) 43. doi: https://doi.org/10.1016/j.ejpe.2012.07.001

6. Pancha, I., Chokshi, K., Mishra, S., Enhanced biofuel production potential with nutritional stress amelioration through optimization of carbon source and light intensity in Scenedesmus sp. CCNM 1077, Bioresource. Technol. 179 (2015) 565.

doi: https://doi.org/10.1016/j.biortech.2014.12.079

7. George, B., Pancha, I., Desai, C., Chokshi, K., Paliwal, C., Ghosh, T., Mishra, S., Effects of different media composition, light intensity and photoperiod on morphology and physiology of freshwater microalgae Ankistrodesmus falcatus-A potential strain for bio-fuel production, Bioresource. Technol. 171 (2014) 367.

doi: https://doi.org/10.1016/j.biortech.2014.08.086

8. Ghosh, P. K., Mishra, S. C. P., Gandhi, M. R., Upadhyay, S. C., Mishra, S. K., Pancha, I., Zala, K. S., U.S. Patent No. $8,741,628$. Washington, DC: U.S. Patent and Trademark Office (2014).

9. Chiu, S. Y., Kao, C. Y., Tsai, M. T., Ong, S. C., Chen, C. H., Lin, C. S., Lipid accumulation and $\mathrm{CO}_{2}$ utilization of Nannochloropsis oculata in response to $\mathrm{CO}_{2}$ aeration, Bioresource Technol. 100 (2009) 833. doi: https://doi.org/10.1016/j.biortech.2008.06.061

10. Santiago, D. E., Jin, H. F., Lee, K., The influence of ferrous-complexed EDTA as a solubilization agent and its auto-regeneration on the removal of nitric oxide gas through the culture of green alga Scenedesmus sp, Process. Biochem. 45 (2010) 1949. doi: https://doi.org/10.1016/j.procbio.2010.04.003

11. Griffiths, M. J., Susan, T. L., Harrison, Lipid productivity as a key characteristic for choosing algal species for biodiesel production, J. Appl. Phycol. 21 (2009) 493. doi: https://doi.org/10.1007/s10811-008-9392-7

12. APHA, 1995. Standard Methods for the Examination of Water and Wastewater, 19th ed. APHA, Washington, DC.

13. Chen, M., Tang, H., Ma, H., Holland, T. C., Ng, K. S., Salley, $S$. $O$., Effect of nutrients on growth and lipid accumulation in the green algae Dunaliella tertiolecta, Bioresource Technol. 102 (2011) 1649. doi: https://doi.org/10.1016/j.biortech.2010.09.062

14. Cheng, D., He, Q., Assessment of environmental stresses for enhanced microalgal biofuel production-an overview, Front. Energy Res. 26 (2014) 1. doi: https://doi.org/10.3389/fenrg.2014.00026 
15. Pal, D., Khozin-Goldberg, I., Cohen, Z., Boussiba, S., The effect of light, salinity, and nitrogen availability on lipid production by Nannochloropsis sp, Appl. Microbiol. Biotechnol. 90 (2011) 1429

doi: https://doi.org/10.1007/s00253-011-3170-1

16. Takagi, M., Yoshida, T., Effect of salt concentration on intracellular accumulation of lipids and triacylglyceride in marine microalgae Dunaliella cells, J. Biosci. Bioeng. 101 (2006) 223 .

doi: https://doi.org/10.1263/jbb.101.223

17. Khatoon, H., Rahman, N. A., Banerjee, S., Harun, N., Suleiman, S. S., Zakaria, N. H., Lananan, F., Hamid, S. H. A. Endut, A., Effects of different salinities and $\mathrm{pH}$ on the growth and proximate composition of Nannochloropsis sp. and Tetraselmis sp. isolated from South China Sea cultured under control and natural condition, Int. Biodeter. Biodegr. 95 (2014) 11

doi: https://doi.org/10.1016/j.ibiod.2014.06.022

18. Jahnke, L. S., White, A. L., Long-term hyposaline and hypersaline stresses produce distinct antioxidant responses in the marine alga Dunaliella tertiolecta, J. Plant. Physiol. 160 (2003) 1193. doi: https://doi.org/10.1078/0176-1617-01068

19. Kirst, G. O., Salinity tolerance of eukaryotic marine algae, Annu. Rev. Plant Biol. 41 (1990) 21. doi: https://doi.org/10.1146/annurev.pp.41.060190.000321

20. Sudhir, P., Murthy, S. D. S., Effects of salt stress on basic processes of photosynthesis, Photosynthetica 42 (2004) 481. doi: https://doi.org/10.1007/S11099-005-0001-6

21. McLachlan, J., The culture of Dunaliella tertiolecta Butcher-a euryhaline organism, Can. J. Microbiol. 6 (1960) 367 doi: https://doi.org/10.1139/m60-041

22. Latorella, A. H., Vadas, R. L., Salinity adaptation by Dunaliella tertiolecta. Increases in carbonic anhydrase activity and evidence for a light-dependent $\mathrm{Na}^{+} / \mathrm{H}^{+}$exchange, J. Phycol. 9 (1973) 273.

23. Hellebust, J. A., A comparative study of sodium andosmotic requirements for growth and nutrient uptake of two related green flagellates, Dunaliella tertiolecta and Chlamydomonas pulsatilla, Archive. Microbiol. 143 (1985) 11. doi: https://doi.org/10.1007/BF00414760
24. Chisti, Y., Biodiesel from microalgae, Biotechnol. Adv. 25 (2007) 294. doi: https://doi.org/10.1016/j.biotechadv.2007.02.001

25. Murata, N., Takahashi, S., Nishiyama, Y., Allakhverdiev, S. I., Photoinhibition of photosystem II under environmental stress, Biochim. Biophys. Acta. 1767 (2007) 414. doi: https://doi.org/10.1016/j.bbabio.2006.11.019

26. Kalita, N., Baruah, G., Dev, G. R., Talukdar, J., Kalita, M. C., Ankistrodesmus falcatus: A promising candidate for lipid production, its biochemical analysis and strategies to enhance lipid productivity, J. Microbiol. Biotechnol. Res. 4 (2011) 148.

27. $X u, X$. Q., Beardall, J., Effect of salinity on fatty acid composition of a green microalga from an Antarctic hypersaline lake, Phytochem. 45 (1997) 655. doi: https://doi.org/10.1016/S0031-9422(96)00868-0

28. Chen, G. Q., Jiang, $Y$., Chen, F., Salt-induced alterations in lipid composition of diatom Nitzschia laevis (Bacillariophyceae) under heterotrophic culture condition, J. Phycol. 44 (2008) 1309 doi: https://doi.org/10.1111/j.1529-8817.2008.00565.x

29. Yao, C. H., Ai, J. N., Cao, X. P., Xue, S., Salinity manipulation as an effective method for enhanced starch production in the marine microalga Tetraselmis subcordiformis, Bioresource. Technol. 146 (2013) 663. doi: https://doi.org/10.1016/j.biortech.2013.07.134

30. Adams, C., Godfrey, V., Wahlen, B., Seefeldt, L., Bugbee, B., Understanding precision nitrogen stress to optimize the growth and lipid content tradeoff in oleaginous green microalgae, Bioresource. Technol. 131 (2013) 188. doi: https://doi.org/10.1016/j.biortech.2012.12.143

31. Rodolfi, L., Zittelli, G. C., Bassi, N., Padovani, G., Biondi, N., Bonini, G., Tredici, M. R., Microalgae for oil: strain selection, induction of lipid synthesis and outdoor mass cultivation in a low-cost photobioreactor, Biotechnol. Bioeng. 102 (2008) 100 doi: https://doi.org/10.1002/bit.22033

32. Mata, T. M., António, A. M., Nidia, S. C., Microalgae for biodiesel production and other applications: A review, Renew. Sustainable Energy Rev. 14 (2010) 217. doi: https://doi.org/10.1016/j.rser.2009.07.020 